\title{
ON ROMANIA'S CROOKED JOURNEY TOWARDS EURO
}

\section{Mircea Teodor MANIU, PhD}

Associate Professor, Faculty of European Studies, Babeş-Bolyai University, Romania mircea.maniu@ubbcluj.ro

\begin{abstract}
This research is focused on the auspices of adopting Euro in the present day economic, social and political junctures of Romania. Starting with the analysis of the economic outlook after the moment of fulfilling the prerequisite macroeconomic criteria, the approach is developed in a particular manner towards the assessment of the domestic social and political conditional ties that are contextually relevant, from a political economy angle, with inflexions towards the current positioning of the domestic political deciding factors. Except for a batch of remarks concerning convergence, the paper does not deal with the specific econometrics of Euro adoption, such as business cycle synchronization or any of the optimum currency area present day debates. Instead it attempts to serve the Euro adoption cause in the predictable future, given the lessons hopefully learned during the years 2015-2016 when Romania was indeed within the Euro compliance margins, but for various reasons never considered taking advantage of this peculiar window of opportunity. Seen from this perspective, combining endogenous with exogenous arguments, mainly of social and cultural consistence, the research is moreover a professional awareness bell for various categories of stakeholders, than an attempt to suggest any sort of normative policy blueprint for such a manifold process as Euro adoption seems to be in this country.
\end{abstract}

Keywords: Macroeconomics, Euro adoption, Romanian economic environment, Social and cultural factors, Economic policy.

\section{Premises}

There are plenty of decent arguments in order to state that at this point in its history the Romanian society would be rather split between the aspirations of being stronger and deeper integrated within EU structures and the more and more vivid public image of quite the opposite, 
in the context of today's Union resets happening under the influence of various national(istic) pressures. Bearing in mind the specter of the confusing history of the so called Romanian "exceptional-ism", dramatically impacting the domestic social and economic life throughout times, more and more voices plead for Euro adoption as a strategic step that would add significant consistency to the overall process of more profound European integration of the country. The common opinion is that either the country will become, procedurally, fully compatible with other Euro Zone (EZ) countries, or we will witness rather soon a process of distancing from the European core and consequently plunging into economic stalemate and overall drift of the country into a periphery that seems unavoidable under these circumstances. All these realities would make a strong incentive to act properly in this ambitious direction.

The fact that the Romanian economy and society was massively exposed to a process of dollarization since the inception of the transition towards free society and market economy, the hard currency (mainly USD and DEM) hedging that was common throughout society during the high inflation period of the early 90s, would make a necessary onset. A decade later, we witnessed a significant volume of remittances that generated a wide popular culture of hard currency and a dedicated market, paralleling the national currency, therefore adding consistence to the statement that Euro adoption would be more or less smooth, both in terms of cognitive and emotional factors. This reality is not necessarily a good premise for Euro adoption, as observes Daniel Dăianu, tackling the issue from the National Bank of Romania's (NBR) macroeconomic perspective. (Dăianu, 2017) Moreover, from the EU's institutional standpoint it is a fact that traditional constraints as well as other conjectural features of the financial system and overall economic outlook of the applying countries matter more and more, increasing the difficulty of the process, just as the recent Euro application submitted by Bulgaria indicates.

The most relevant grand stand suggesting the lack of consistency of a speedy transition towards Euro adoption in Romania became public late in 2016. (Dăianu et al., 2016) A comprehensive and professionally built macroeconomic study, this paper incorporates all the conceivable arguments of economic consistency against speedy Euro adoption. Dealing with the issue from several macroeconomic perspectives, starting with the distance between the theoretical and practical aspects of the European Monetary Union (EMU) and analyzing the evolution of EZ's institutional 
framework and policies, the study conveys the clear message that Romania should not adopt the Euro under the 2016 conditions. Actually, the depiction of the investigated prospect of the Romanian national economy, finance and banking systems, when benchmarked to those corresponding within EZ, makes the most reputed economic newspaper of the country to label this academic output as "the most pessimist study about the adoption of Euro in Romania...". (Pâslaru, 2016) Since that moment the horizon of the accession process somehow trailed off in our country, nowadays (September 2018) only 1 out of 4 criteria being fulfilled. (European Commission, 2018)

The approach has strongly impacted on media, with immediate negative labels, but definitely has its straightforward merits of macroeconomic consistence. But we must observe also that the reasons invoked, combined with the political establishments' reluctance to approach systematically and constructively the issue, apparently due to estimated negative impacts on the overall standard of living, or to the foreseen deepening of territorial discrepancies, fueled the engine of postponement, more or less sine die. Bluntly said, the steps of the path toward Euro, clearly expressed in the following lines were simply not a political issue in 2017 and 2018. "It is very important to have the time horizon for the accession process clearly in mind. The full integration process is characterized by three major stages: first membership in the European Union; second, membership in the Exchange Rate Mechanism (ERM) II; and third, membership in the Euro-system, thus the adoption of the Euro as the single currency. This will be the path for new members, as it has been and will remain the path for the present EU members" (Solans, 2001).

Meanwhile one can observe that even less effort, if any of this sort of amplitude and consistency, was dedicated to the investigation of the Euro adoption from a multidisciplinary perspective, culturally, socially, politically or even geopolitically layered. Arguments of such consistence were occasionally stigmatized by economists as "soft" and therefore unworthy to interfere with such an econometrically patterned process. I believe that the pan-European public debate concerning the alternative scenarios for the future of EU, as presented in the EC's White Paper issued on February 22, 2017 would significantly change this outlook due to the fact that more and more people would perceive the de facto process of splitting EU into EZ and non EZ or even worse, in more layers, with the obvious negative consequences for a country such as Romania. Or, alternatively considering this larger research framework and putting it in Peter 
Drucker's programmatic words: "The policies that worked in the last forty years were very different from those development economists and development politicians advocated." (Drucker, 1989) It makes a lot of sense, I believe, to tackle the issue from this angle too, as for instance Jeffrey Sachs does when expressing his concerns about the diminishing international stature of the US dollar due to present day American administration wrong policies and their even worse reflection on the world stage. (Sachs, 2018)

Last but not least in this row of ideas, we must debate the topic at a time when the single currency was adopted, one by one, by several CEE countries namely Slovenia, Slovakia and the Baltic countries. They are proof that the propensity to adopt the common currency stands valid today too, despite the rather bumpy history of the Euro during the last decade. No doubt there is plenty of common sense in the idea that without a competitive economy, structurally EZ compatible, there is no point in a politically rushed Euro adoption. But positioning a country as firmly as possible in the dispute "Big bang vs. gradualism" adoption policies, as Fidrmuc (2003) labels them during the early days of the Euro, becomes a more and more relevant dichotomy pattern, during these days plagued by Euro-skepticism. Moreover, under the new set of constraints

of mainly extra-economic and geopolitical consistence, having a clear commitment, just as our Southern neighbor Bulgaria, a firm anchor for Euro adoption and consequently coherent dedicated institutions, policies and procedures covering this business, seems to be the most appropriate if not the only path enabling deeper economic integration of Romania within EU.

\section{The mixed-up EU-RO political economy}

Beyond the wordplay of the section's title, the period between annus mirabilis 1989 for CEE and annus horribilis 2016 for the whole EU was indeed a time of massive economic and social changes throughout Europe. It is also beyond doubt that the decades that followed the demise of the communist regimes made their marks on the fabric of the societies of CEE, probably just as heavily as the previous decades were marked by the totalitarian doctrine. The "stampede of Western liberalism" that characterized life in countries such as Romania coexisted with a wave of relative resilience towards neo-liberal ideas in the Western European economic environment of the last quarter of the XXth century (Schmidt and Thatcher, 2013) and occurred in a landscape illustrated by scarce public administration reform (Mora and Țiclău, 2008). The last (and worse) 
European aperture, of illiberal consistence added a significant dimension to the entropy of the political and economic environments. Therefore, the failure to properly deliver the initially forecasted results of European integration, Euro adoption included, could be considered a direct consequence of the significant gap between the rhetoric of policy deciders and the daily reality of erratic economics, lack of convergence, business cycle (lack of) synchronization, etc.

The Stability and Growth Pact and the associated Stability Programs are imposing on candidates balanced budgets, the acceptance of the signals sent by the early warning indicators and to conduct appropriate actions in case of any wrongdoing. The single supervisory mechanism and the single resolution mechanism along with the European deposit insurance scheme would complete the track towards the Banking Union, also as a preliminary step. In the situation of Romania there was enough constructive, one might say visionary, political momentum in order to sign in 2012 the Fiscal Compact, namely chapter III of the Treaty on Stability, Coordination and Governance, thus voluntarily undertaking supplementary automatic correction measures consistent with the Medium Term Objective. Such kind of political approach cannot be interpreted otherwise but as prudential and worthwhile for the long run outlook of our economy, particularly if the landscape is evaluated in the present day (2018) Romanian juncture.

This actually means that countries that do fulfill nominal criteria, but somehow fail to fully comply with other real prerequisites, could theoretically still be admitted in the EZ provided the fact it is obvious they are considered reliable from an overall economic perspective. It is precisely this track, implying a faster procedure towards the Euro that was seen as the most profitable for present day economy's climax, by significant authors, thus opposing the more or less quasi-official position of indefinitely postponement. (Cerna, 2018a) It is also contextually important to underline the reality that from the European Central Bank's (ECB) perspective, no additional criteria than those applied to EZ countries should be imposed on the applicants. Sustainable convergence measures and their thorough application must be the absolute pragmatic priority of each country and not the very debate on when and how Euro should be adopted. Can we say that Romania complies with this basic pragmatic request today? Definitely not, but any advised observer of the phenomenon could say that today such this is the mood throughout Central and Eastern Europe 
(CEE), in practically all those countries that are supposed to adopt the common currency according to their accession treaty.

Facing the reality that Euro adoption is, no matter how we take it, an elitist project, at this point available only to the chosen ones, but contractually unavoidable on the long run, several Euro adoption anchors were thrown in Romania in time, the rationale behind them being mostly to uphold the issue in terms of public relations than introducing a feasible benchmark. From the initial one in 2014, seven years past joining EU in 2007, to the symbolic year 2019, when Romania will hold for the first time the Presidency of EU's Council (Lungu, 2012) up to the recently unveiled 2024, there is no lack of Euro inception benchmarks in this country. The conformity of the nominal criteria for the previous three years, but also the fact that the country currently reached, according to Eurostat data, almost $60 \%$ of EU 28's average GDP (PPP) per capita while being the EU champion of growth rate in both 2016 and 2017 seemed insufficient in order to gather critical mass for an affirmative political decision in this respect. But even worse, the manner of coordinating the process since joining EU, up to this moment by the NBR, since 2018 by several institutions under the coordination of the Government (Guvernul României, 2018), was somehow crooked and effectively lies under ambiguous auspices, as quite recently even the President of the country stated. (Buican, 2018)

Between the two temporal benchmarks invoked in the opening, our country had a truly peculiar economic track, evolving on eclectic coordinates. Since the beginning of the transition period, domestic policies focused more than anything else on the exogenous constraints induced by the request to build a functional market economy out of the most obsolete and conservative economic system CEE could see during the late " 80 s. Actually, no matter of the "waves" such a move would have implied, the desire of belonging to the EU was a matter of national consensus, even to a larger extent than in other CEE countries, and therefore the economic distortions, (Mattli and Pluemper, 2004) sometime painful adjustments, apparently exogenously imposed, were willingly accepted. But the unconventional, stop and go type of process of conveying towards free market, starting from the realities of Romania, marked the country in a peculiar way. EU became the formal benchmark in all respects, particularly due to the observed comparative inefficiency of the domestic political class, but also the "whipping supervisor" easy to blame for a various set of 
transition liabilities. Overall, as series of Eurobarometers reveal, the Euro-enthusiasm, measured on various layers of the society peaked in the country more than anywhere else in the region. No wonder in this context than joining as soon as possible the EZ was in the plan even since acceding to EU in 2007 (Isărescu, 2014).

We must face it: gradually, Romania got in line with other CEE countries in this respect. Much of the Euro-skepticism that can be observed today in both professional and common European milieus and even beyond has much to do with the lack of appropriate reforms of the European monetary system. This conclusion surfaced following the Greek bail-out and the reluctance to debt mutual tackling, revealing significant heterogeneity between financial markets, to the extent that the only applicable solution was the acceptance by the ECB of quantitative easing measures that would be shared by all the players of the financial game. (Balcerowicz, 2012) So, an increasing lack of confidence in the future of the common currency acquired more and more ground, attitude that draws both from its birth sins (in some views a utopian vision derived from political targets) and from the Euro adoption route setbacks. These realities are vividly indicated by the evident gaps of various consistencies between the so called Northern richer flank of EZ and the less rich Southern one (Joffe, 2012) and more obscurely by the increasingly wider policy gap between liberal and illiberal politicians throughout EU. It is precisely this shaky balance between the hard values of the EU, that are obviously epitomized by Euro, and the national interest that is politically parameterized to convey to different values, that probably explain best the crooked Euro adoption policies in Romania.

\section{Macroeconomics, Geo-economics and Culture}

Why adopt Euro when its demise has been proclaimed by many important observers? Such an outcome would be theoretically perfectly illustrated by Joseph Stiglitz' radical pessimistic views, largely shared today throughout CEE. In his comprehensive Euro: How a Common Currency Threatens the Future of Europe he deals with unmatched accuracy on the failure of Euro to deliver according to the plan. (Stiglitz, 2016) Even if the last chapter indicates a couple of potential remedies, the overall conclusion seems obvious: the European single currency system is doomed. It is a fact that Euro-skepticism is mostly of American consistence (Cerna, 2018b) but gradually many Europeans became more and more influenced by this kind of view following the global 
crisis. (Gibson et al., 2014) It is precisely this induced mood that has nowadays an unhealthy influence over the position of macroeconomists and econometricians concerned with the adoption or rejection of the common currency. (Ryc, 2015) Obviously this generates a complex procrastination climate that does not take much in consideration many political happenings of 2017, positive or negative, such as Brexit, external threats of various kinds, or the open attempts to reform the Union by launching the alternative scenarios for further evolution.

This being the crux, it seems only logic that significant policy differentiations concerning the issue of Euro adoption have emerged in those countries that should adopt Euro, often fuzzy approaches that were intensified by various political interests and not necessarily by authorized voices of the economic establishment. We must acknowledge in this respect that many cultural biases play a peculiar role in the process of deeper integration within EU structures in general, belonging to EZ in particular. One could find the most solid grounds for considering the peculiar cultural reasons of adopting a supra-national currency in Hayek's Denationalization of Money. (Hayek, 1990) In several editions, since 1976 till 1990, it is described how the world got used to the existence of a distinct national currency in each country, currency that is most often considered as natural, a very must for structuring the economy, for balancing the level of domestic prices as they move together relatively to the price levels pattern of other countries. In other words an economy gets rooted in its currency and the proportionality of this process would be generated by the overall success of that particular economy and this generates specific territoriality of geoeconomic consistence. Newer approaches of the kind link the issue to the so called "convergence trap" that allows more competitive Euro countries to exploit de facto the weaker ones through trade and financial channels, beyond the classic political bullying and thus actually acting as a divergence factor. (Pruchnik and Zowczak, 2017)

As one of the most reputed pioneers of the theory and practice of the European Monetary System diagnoses, "culture can be easily brought to the realm of economics judging it as a public good". (Kindleberger, 2000) Sometimes public values emerge naturally; sometimes they should be imposed, always only for the benefit of recipient societies. True, these public goods are in many cases also symbolic, money included, so they should be conceived in such a manner that starting from a certain representation of an idea, fact or history, they should generate the situation that a 
certain social layer, not necessarily the whole society, reaches critical mass in order to perform a crucial task in front of that particular society, at that specific moment. Factors external to the phenomenon itself could trigger significant socio-cultural changes. (Sorokin, 1970) I would say that Euro undoubtedly played such a symbolic role in several countries, if not all of them, evidently beyond its basic monetary functionality. In fact, in many material and non material ways it encapsulates the very essence of the European process of integration, as seen both from inside and outside the EU. Ignoring this cultural feature would mean to self-inflict a strategic wound, especially if the case is about a smaller, less exposed to the world economic flows, country, economy and society.

So, restating the undeniable connection between extra-economic elements, of mainly cultural consistence, as observed in economic history by Mandeville, Hume, or Hayek we shall clearly observe this "competition" between vital traditions and modern practices. It is a fact that only the latter are objectively shaping the true path towards Euro and it seems that the process of analyzing whether Euro adoption should be accelerated as much as possible, or quite the opposite, in present day Romania, should be interpreted also from this professional culture's angle. "What culture establishes is moral order. Culture regulates right and wrong, lays down what attracts reward and what attracts punishment. It offers a model of the good life and establishes a complex web of obligations, rights and duties" (Schoepflin, 2012). After all, during the whole transition process Romania, as well as other CEE countries, was constantly in search of moral order benchmarks, unfortunately so seldom found in our society. Linking the process of Euro adoption exclusively to the rigid econometrically built framework simply does not offer the social impetus necessary in moments like this. In 2014 only 36\% of Latvians supported the Euro adoption, but the country being fully prepared acted accordingly. (Fontanella-Khan and Milne, 2013). Today Romania is still the most Euro adoption enthusiast country in EU, 54\% of the Romanians believing that such a monetary step would have positive consequences for the country, but an even larger batch, namely 68\% support the fast adoption! (European Commission, 2015)

It is definitely not my purpose to depict in this paper the state of process seen from the macroeconomic angle. I will use only one indicator here, for a comparative approach purpose, contextually relevant, I believe. In terms of convergence, it is a fact that the Romanian economy 
fulfilled the nominal criteria between 2015-2017 and, as observed from Eurostat data, generated a GDP (PPP) per capita convergence level of 57\% of EU 28's average in 2016, a figure that is comparable with Slovakia's at the moment of Euro adoption there, the strong 2017 of $7.1 \%$ (2018 estimations are also in this vicinity) being poised to improve this percentage, in simple econometrics, to an estimated level of around $62 \%$. Isn't this comparative level of convergence relevant for Romania? Indeed, as the Governor of NBR observed that "even though there are no accurate criteria indicating sufficient real convergence for the successful Euro adoption, a common-sense benchmark would be the minimum real convergence level at which new member states entered the Euro area - 58.3\% for Estonia, 59.6\% for Latvia, 65\% for Slovakia”. (Isărescu, 2015) Mirroring this situation we would appreciate that in the presence of sufficient structural convergence, a real convergence rate over $60 \%$ is enough to accommodate the common monetary policy and thus giving a green light to Euro adoption.

When the country joined EU in 2007, NBR assessed that it will take 5 years in order to join ERM II and consequently Euro adoption will occur in 2014. Conditions were met in 2015 but the reluctance to adopt the common currency was mainly explained (actually all throughout CEE) by the huge negative effects of the global crisis that hit the world in 2007. (Gajewski, 2016) This was the main reason for various governments to openly oppose the move, due to concerns over the economic dynamics following adoption. A major theme of the opponents of a faster track towards Euro was and still is the vulnerability induced by the developmental discrepancies among the regions of a certain country, triggered by a mechanism that inexorably leads to more discrepancies that the opposite. (Fingleton et al., 2015) In the case of Romania, we probably should supplement, not replace, such an argument with the conclusions derived from information concerning the superior pace of development of several Romanian regions today (Milken Institute, 2017) and start analyzing the overall countrywide driving effect of some regional really dynamic clusters and their spinoff effect. But once more, the cultural bias, always emerging when the question is about participating or not to such an optimum currency area as EZ, it is clearly a stronger issue in other countries as in Romania.

A country with a proven resiliency to harsh economic and monetary conditions, heavily tested by inflation the $90 \mathrm{~s}$, with a consequent dollarization process, as well as the de facto Euro-ization 
during the 2000s, following the massive emigration of Romanians towards EZ states, probably can cope decently the initial macroeconomic adjustment period. Such a country could definitely culturally cope even better with the inherent micro and macro initial shocks and setbacks involved by the move. Let me give a petty example here: investigating the current use of Euro banknotes, 7 out of 10 Romanians are fully aware of them, while less than 4 Poles would fit in the same situation. Romania has also the highest proportion of people (62\%) who consider that EU institutions are more trustworthy than the equivalent in their own country. (European Commission, 2017) Again, invoking the Slovak example, because I believe it is contextually relevant, this country has seen robust growth after joining the EZ, whilst its former federate partner, the Czech Republic, which decided to remain independent and keep its old crown, has done comparatively worse. (Monfort, 2017)

It is clear that general entropy, either of economic and/or political consistence, or "lack of smoothness", to say the least, in the evolution of EZ could have important and severe repercussions for the emerging economies, such as Romania's. (Maniu, 2014) So, no matter if the country embarks, willingly or forcefully on the Euro track, or opposes it by all means, the long range outcome could be forecasted with reasonable accuracy as more or less the same in terms of harmonizing business cycles. It is quite indicative to notice in this framework that Poland, the country that is strongly opposing today Euro adoption (it is not by chance that this paper uses more Polish sources than any other in terms of comparative approach) simply cannot have an efficient countercyclical policy due to various exogenous constraints. (Janikowski, 2018) So, It seems to me that for those opposing Euro adoption, in Romania or else, though accepting the rationale of both the status quo and of the institutional change that will inevitably occur in the years to come, the genuine economic question that arises regards not the very adoption but the impact and sustainability of such an action, in other words and methodologically speaking an outcome that could be properly described only with means beyond the clear macroeconomics of Euro adoption.

\section{Can we conclude on the matter?}

Summing up and interpreting both exogenous and endogenous factors speeding or delaying Euro adoption, I would say that there is no better "public good" to restate Kindleberger's formula, that could underline Romania's dedication towards deeper European integration than at least 
attempting through proper institutional means to join the EZ as soon as possible. From both cultural and social perspectives, such an approach fully resonates with the recent years' developments within the Romanian society. From the macroeconomic standpoint it would be a daring move, but definitely not a hazardous one, as relevant voices claim. (Cerna, 2017) No major economic disequilibrium could be forecasted, grounded on the available data. Strictly from the political economy angle, even the harshest introductory period would not generate major economic and social malfunctions. But on the other hand, postponing adoption without a clear anchor would certainly induce a counterproductive mood that would sooner or later affect the outlook of the rather sound economy today, not for long, as consistent assessments predict. Lack of certainty about the future is precisely the reason for a clear strategy (Bradley, Hirt and Smit, 2018) the opposite being simple ignoring the developments, always and everywhere with worse consequences.

Can and/or should Euro adoption become a case of self fulfilling prophecy in the present juncture of the Romanian economy and society? Acceding to the EZ would be indeed a situation that could boost the nation's energies in the years to come, but obviously this process has also embedded liabilities, hidden traps that could overturn the whole operation into its opposite. From an axiological perspective this is a link to superior norms that are supposed to boost morale and implicitly overall social efficiency. It is probably the fear of failure in coping with higher economic benchmarks imposed by the use of the common currency that made several eligible CEE countries (Czech Republic, Poland, Hungary) to postpone the adoption of the Euro, while others (Slovenia, Slovakia, the Baltic countries) boldly moved forward without jeopardizing their growth and developmental trajectories. Moreover, if the expectations of a clear cut between EZ and nonEZ countries are going to be fulfilled in the foreseeable future, the "fall out" from the status quo could strongly jeopardize the chances of a country to a fair position within EU. This argument, obviously grounded on reasons of political strategic thinking mere than anything else, is perennial for those embracing the idea of moving faster towards the Euro, despite the adversities and unforeseen dangers.

It is my point that without reliable governmental measures, public debates, specific institutional buildups with proper social impact (Cojanu, 2010) and meanwhile constant EU 
benchmarking, lower induced expectations or no expectations at all, cannot but generate a weaker performance towards a future goal of Euro adoption even if the macroeconomic prerequisites would be in place. What is called in psychology and sociology the Rosenthal effect of the proportionality between induced expectations and results accomplished, would be automatically replaced by its corollary, namely the so called Golem effect, straightforwardly leading to the decrease of the overall performance following the lack of adequate economic landmarks as social stimuli. While the intricacies of the Euro adoption mechanism unquestionably fall in the responsibility of the professionals of the economy, the responsibility to improve as soon as possible the existing design of the country's Euro adoption blueprint, from the political economy's angle, falls at this point in history almost entirely on the shoulders of the existing political class.

\section{References}

1. Balcerowicz, L. (2012) Eurozone I: Bail-outs are no substitute for reforms, in Europe's World, No. 20 (Spring), pp. 74-77.

2. Bradley, C., Hirt, M., Smit, S. (2018) How to confront uncertainty in your strategy, Mc Kinsey [https://www.mckinsey.com/business-functions/strategy-and-corporate-finance/ourinsights/how-to-confront-uncertainty-in-your-strategy] Accessed May 15, 2018.

3. Buican, A. (2018) Critici aduse Guvernului de Johannis pentru Comisia de adoptare a euro: "Eu nu o să fac un comitet sub coordonarea Administraţiei prezidenţiale", in Capital, March 23, [http://www.capital.ro/iohannis-despre-adoptarea-monedei-euro-in-2024-am-iesit-dinmar-1.html] Accessed March 26, 2018.

4. Cerna, S. (2017) Adoptarea Euro: şansă şi provocare pentru România, in Sinteza, No. 47, December 2017 - January 2018.

5. Cerna, S. (2018a) Efectele adoptării Euro, Ora nouă, March 27, [http://www.oranoua.ro/silviucerna-efectele-adoptarii-euro/] Accessed April 2, 2018.

6. Cerna, S. (2018b) Euro şi bătălia de idei, Contributors, August 30, [http://www.contributors.ro/economie/euro-\%C8\%99i-batalia-de-idei/] Accessed September 3, 2018.

7. Cojanu, V. (2010) Logica raţionamentului economic, Editura C.H. Beck, București, pp. 129 141 
8. Dăianu, D., Kallai, E., Mihailovici, G., Socol, A. (2016) România și aderarea la zona Euro: întrebarea este în ce condiţii! IER, Bucharest, [http://www.ier.ro/sites/default/files/pdf/SPOS_2016_Romania_si_aderarea_la_zona_Euro.p df $\backslash$ Accessed February 7, 2017.

9. Dăianu, D. (2017) De-euroizarea și aderarea la zona euro: o contradicţie? Opiniibnr.ro, May 2, [http://www.opiniibnr.ro/index.php/macroeconomie/201-de-euroizarea-si-aderarea-lazona-euro-o-contradictie] Accessed June 20, 2018.

10. Drucker, P. (1989) The New Realities, Harper and Row, New York, p. 148.

11. European Commission (2017) Convergence Report 2016, Institutional Paper 026, (June) [https://ec.Europa.eu/info/sites/info/files/file_import/ip026_en_2.pdf]_April 10, 2017.

12. European Commission (2018) Convergence Report 2018, Institutional Paper 078, (May) [https://ec.europa.eu/info/sites/info/files/economy-finance/ip078_en.pdf] Accessed July 9, 2018.

13. Fidrmuc, J. (2003) Optimal Path into the EMU: Big Bang or Gradualism? in Aiginger K. , Hutschenreiter G. (Eds): Economic Policy Issues for the Next Decade, Springer, Boston, MA, pp. 123-139.

14. Fingleton, B. , Garretsen, H., Martin, R. (2015) Shocking aspects of monetary union: the vulnerability of regions in Euroland, in Journal of Economic Geography, 15(5), pp. 907-934.

15. Fontanella-Khan, J. , Milne, R. (2017) Latvia launches bid to join Euro, in Financial Times Europe, March 4. [http://www.ft.com/cms/s/0/bef93cc2-84df-11e2-88bb00144feabdc0.html\#axzz2blYXNFUR $\$ Accessed February 16, 2017.

16. Gajewski, P. (2016) Monetary Policy Stress in EMU: What Role for Fundamentals and Missed Forecasts? in Emerging Markets Finance and Trade, 52(5), pp. 1226-1240

17. Gibson, H. D. , Palivos, T., Tavlas, G. S. (2014) The crisis in the Euro area: an analytic overview, in Journal of Macroeconomics, No. 39, pp. 233-239..

18. Guvernul României (2018) Ordonanța de urgență nr. 24/2018 privind înființarea, organizarea și funcționarea Comisiei Naționale de fundamentare a Planului național de adoptare a monedei euro, Monitorul oficial, March 28, [https://lege5.ro/Gratuit/gi3tkmbqgi4q/ordonanta-deurgenta-nr-24-2018-privind-infiintarea-organizarea-si-functionarea-comisiei-nationale-defundamentare-a-planului-national-de-adoptare-a-monedei-euro], Accessed May 25, 2018. 
19. Hayek, F.A. (1990) Denationalization of Money: The Argument Refined. An Analysis of the Theory and Practice of Concurrent Currencies, London, The Institute of Economic Affairs, pp. 113-117.

20. Isărescu, M. (2014) România și adoptarea monedei Euro. Dissertation held on the occasion of recieving the title of Doctor Honoris Causa of the University of Bucharest. Bucharest, February 20 http://www.bnr.ro/Prezentari-si-interviuri-1332.aspx?fld_menu_name=Mugur\%20Is\%C4\%83rescu], Accessed September 15, 2017.

21. Isărescu, M. (2015) Nominal convergence versus real convergence. Romania's Path towards Euro, Conference, April 20, National Bank of Romania, Bucharest .

22. Janikowski, L. (2018) What Is the Quality of the Fiscal Policy in Poland? CASE No. 82 [http://www.case-research.eu/files/?id_plik=5627)] Accessed July 31, 2018.

23. Joffe, J. (2012) Eurozone II: The case for mudding through in Europe's World, No. 20 (Spring), pp. 78-82.

24. Kindleberger, C. (2000) A new bi-polarity? in: Mundell, R., Clesse, A. (Eds), The Euro as a Stabilizer in the International Economic System, Kluwer Academic Press, Boston/Dordrecht/London, pp. 3-20.

25. Lungu, L. (2012) Interview about Euro adoption, in Newsletter IER, No. 52 (April), pp. 1-2.

26. Maniu, M.T. (2014) Reconsidering the Adoption of the Euro in Today Romania, in Păun, A.C., Păun, D. (Eds), The convergence of Diversity. The European Model, Cluj-Napoca, Presa Universitară Clujeană, pp. 281-287.

27. Mattli, W., Pluemper, T. (2004)The Internal Value of External Options, in European Union Politics, No. 3 (September), pp. 312-325.

28. Milken Institute (2017) Best-Performing Cities-Europe Rankings, [http://www.milkeninstitute.org/publications/view/895.] Accessed December 11, 2017.

29. Monfort, J. (2017) The Czech Republic vs. Slovakia: Why One Benefited by Joining the Euro, in Pound Sterling, September 20 [https://www.poundsterlinglive.com/economics/5481-a-tale-of-twocountries-one-that-joined-the-Euro-and-one-that-didn-t.] Accessed April 3, 2017.

30. Mora, C. M., Țiclău, T. (2008) Managerial Approach to Public Administration, in Transylvanian Review of Administrative Sciences, No. 24E, pp. 87-97.

31. Pâslaru, S. (2016) Cel mai pesimist studiu despre aderarea României la zona Euro: abia peste nouă ani vom fi în stare, in Ziarul Financiar, November 16 [http://www.zf.ro/eveniment/cel- 
mai-pesimist-studiu-despre-aderarea-romaniei-la-zona-Euro-abia-peste-noua-ani-vom-fi-instare-15963791]Accessed March 28, 2017.

32. Pruchnik, K., Zowczak, J. (2017) Is the "Convergence Trap" the New Risk for the CEE and CIS?, in CASE No. 48 [http://case-research.eu/files/?id_plik=5242] Accessed December 12, 2017.

33. Ryc, K. (2015) Convergence and competiveness: problems for the Polish economy in the European Union, in The European Union and Poland, Adamcczyk, A., Dubel, P., Eds. Centre for Europe, University of Warsaw, pp. 103 - 124.

34. Sachs, J. (2018) Trump's Policies Will Displace the Dollar Project Syndicate, September 3, [ https://mailchi.mp/c329a3c5eb1e/jeffrey-sachstrumps-policies-will-displace-thedollar?e=c3a9414151] Accessed September 4, 2018.

35. Schmidt, V.A., Thatcher, M. (2013) Theorizing ideational continuity: The resilience of neoliberal ideas in Europe, in: Schmidt, V.A. , Thatcher, M. (Eds), Resilient Liberalism in Europe's Political Economy, Cambridge University Press, Cambridge, pp. 1-10.

36. Schoepflin, G. (2012) What are Cultures? In Report on The Global Round Table Sustainability of Culture, The Greatest Challenge of the $21^{\text {st }}$ Century, Budapest, pp. 17-18.

37. Solans, E.D. (2001) Some remarks on the future of the Euro. European Central Bank, [https://www.ecb.Europa.eu/press/key/date/2001/html/sp011129.en.html]

38. Accessed March 21, 2017.

39. Sorokin, P. (1970) Social and Cultural Dynamics. A Study of Change in Major Systems of Art, Truth, Ethics, Law and Social Relationships, Horizons Books, Boston, pp. 630-638

40. Stiglitz, J.E. (2016) Euro. Cum amenință moneda comună viitorul Europei. Editura Publica, Bucharest, pp. 78-82. 